\title{
Effectiveness of cognitive rehabilitation after drug therapy on brain function and behavioral symptoms of children with ADHD in Ahvaz
}

\author{
Seyedhamidreza Seyedmohammadi ${ }^{1}$, Parvin Ehteshamzadeh ${ }^{2}$, Fariba Hafezi ${ }^{3}$, Reza Pasha $^{4}$, \\ Behnam Makvandi ${ }^{5}$ \\ 1-Ph.D. student of General Psychology, Ahvaz Branch, Islamic Azad University, Ahwaz, Iran. \\ 2- Assistant Professor, Department of Psychology, Ahvaz Branch, Islamic Azad University, Ahwaz, Iran \\ (Corresponding Author). $\quad$ E-mail: p_ehtesham85@yahoo.com \\ 3- Assistant Professor, Department of Psychology, Ahvaz Branch, Islamic Azad University, Ahvaz, Iran. \\ 4- Associate Professor, Department of Psychology, Ahvaz Branch, Islamic Azad University, Ahvaz, Iran. \\ 5- Assistant Professor, Department of Psychology, Ahvaz Branch, Islamic Azad University, Ahvaz, Iran.
}

Received: 19/07/2019

Accepted: 22/10/2019

\begin{abstract}
Introduction: Hyperactivity Disorder is a neurodevelopmental disorder.

Aim: The purpose of this study was to compare the effectiveness of curative drug therapy and cognitive rehabilitation on the active memory of children with attention deficit hyperactivity disorder in Ahvaz city.

Method: The sample consisted of 45 from students with ADHD (two groups of 15 experimental and one control group of 15) who were selected by multi-stage random sampling. The research method was pre-test, post-test, and follow-up with the control group. For collecting data, questionnaires were used to test the prevalence of direct cultivars.

Results: For analyzing the data, covariance analysis, Bonferron's post the pursuittest and SPSS software were used. The results of the study showed that cognitive rehabilitation has a different effect on the active memory of children with attention deficit hyperactivity disorder in relation to drug therapy. In other words, the effect of cognitive rehabilitation on active memory was more effective than drug therapy, which has been continued in the follow-up phase of 1.5 months.
\end{abstract}

Conclusion: Therefore, it can be concluded that the treatment of children with attention deficit hyperactivity disorder by cognitive rehab has more and better effects for the treatment of chidren with attention deficit hyperactivity disorder.

Keywords: Stimulants drugs, Cognitive assessment, Active memory, Children with hyperactivity disorder

How to cite this article : Seyedmohammadi S, Ehteshamzadeh P, Hafezi F, Pasha R, Makvandi B. Effectiveness of cognitive rehabilitation after drug therapy on brain function and behavioral symptoms of children with ADHD in Ahvaz. Shenakht Journal of Psychology and Psychiatry. 2019; 6 (5): 129-140 .URL: http://shenakht.muk.ac.ir/article-1-673-fa.pdf

Copyright (C) 2018 the Author (s). Published by Kurdistan University of Medical Sciences. This is an open access article distributed under the terms of the Creative Commons Attribution-Non Commercial License 4.0 (CCBY-NC), where it is permissible to download, share, remix, transform, and buildup the work provided it is properly cited. The work cannot be used commercially without permission from the journal. 


\title{
مقايسه اثربخشى دارودر مانى و توانبخشى شناختى بر حافظه فعال كودكان مبتلا به اختلال ADHD شهر اهواز
}

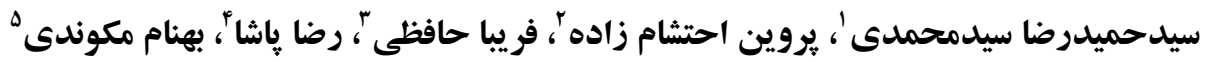 \\ ا.دانشجوى دكترى تخصصى روان شناسى عمومى، واحد اهواز، دانشگاه آزاد اسلامى، اهواز، ايران.

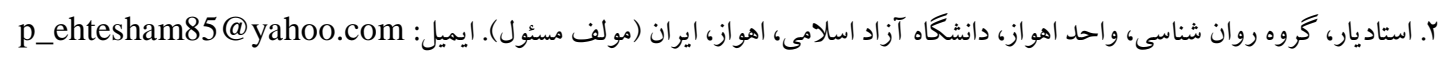

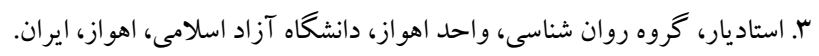

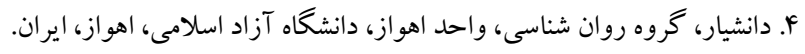

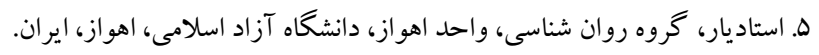

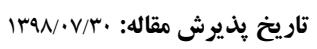

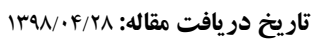

جكيده

مقدمه: اختلال نقص تو جه بيش فعالى اختلال عصبى - تحولى است.

هدف: يثوهش حاضر با هدف مقايسه اثربخشى دارودرمانى و توانبخشى شناختى بر حافظه فعال كود كان مبتلا به اختلال نقص توجهبيش فعالى شهر اهواز اجرا كرديد.

روش: نمونه يزٔوهش شامل ها نفر (دو گروه ها نفره آزمايش و يك گروه ها نفره كنترل) از دانش آموزان مبتلا به اختلال بيش فعالى

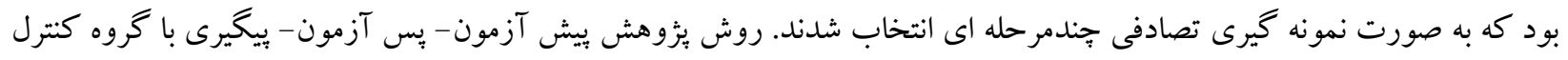
بود و جهت جمع آورى داده ها از ير سشنامه هاى آزمون فراخناى ارقام مستقيم استفاده شد. يافته ها: براى تحليل دادهها از روش تحليل كواريانس و آزمون تعقيبى بنغرونى و نرم افزار اس بيى اس اس استفاده شد. نتايج به دست

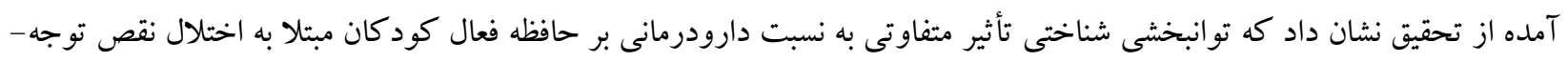

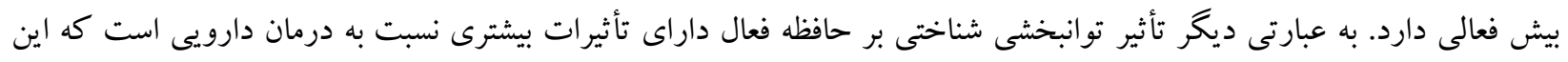

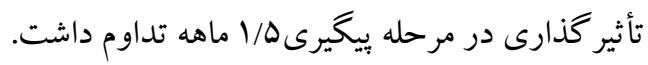

نتيجه كيرى: بنابر اين مى توان نتيجه گرفت درمان كود كان داراى نقص توجه- بيش فعالى به وسيله توانبخشى شناختى داراى تأثيرات بيشتر و بهترى براى درمان كود كان مبتلا به اختلال نقص توجه- بيش فعالى است. كليدوازه ها: داروهاى محرك،، ارزيابى شناختى، حافظه فعال، كود كان مبتلا به اختلال بيش فعالى 
يكى از شايع ترين اختلالات دوران كودكى كه توجه روان شناسان و روان بزشكان را به خود جلب كرده، اختلال كمبود توجه/ بيش فعالى است. اين اختلال

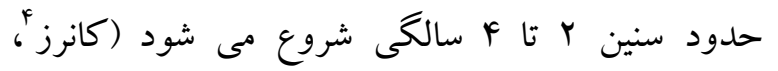
( $($ r $\cdot Y$ بر اساس DSM -5 سميتوم هاى نقص توجه بيش فعالى معمولاً در ب سالكى حضور دارند اما كود كى معمولاً مبتلا به اين اختلال دياكنوز نمى شود تا زمانى كه به كودكستان يا دبستان برود و در آن جا معلم بتواند او رابا لهاب ساير كود كان همسن مقايسه كند (سادوكك و همكاران،

يكى از روشهاى درمانى براى نقص توجه بيش فعالى،

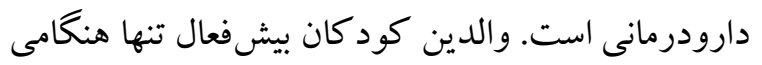
دارو درمانى را مى بذيرند كه از مداخلات رفتارى و

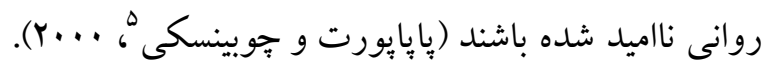
محرك ها نخستين طبقه از تركيباتى بودند كه براى

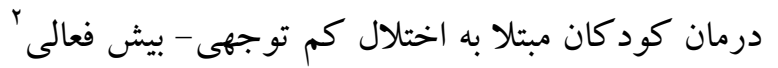
معرفى شدند؛ رايج ترين تركيبات اين طبقه شامل متيل فنى ديت (ريتالين و مانند آن)، دى آمفتامين (دكسترين) و منيزيم يمولين (سيلرت) مى شود. داروهاى محرك، بيش فعالى حركتى و رفتارهاى تكانشى را كم كرده و به فرد امكان مىدهند تا توجه خود را بر موارد و موضوعها

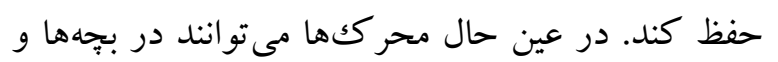
نوجوانان نقص توجه- بيش فعالى و نيز درمان بيماران عقب مانده ذهنى مبتلا به اين اختلال مؤثر باشند و به به به عنوان درمان كمكى براى مداواى اختلالهاى خلقى

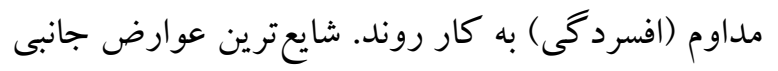

4- Conners

5 - Pappaport \& Chubinsky

2- ADHD

\section{مقال}

بر اساس DSM -5 تعريف اختلال كم توجهى/ بيش فعالى يك عارضه عصبى- روانى است كه كودكان، نوجوانان و بزركگسالان رادر سراسر جهان به خود مبتلا مى كند و مشخصه اصلى آن كمبود توجه (ناتوانى در ادامه دادن توجه)، تكانش گرى و بيش فعالى است. تحقيقات مرتبط با سميتوم هاى نقص توجه بيش فعالى هنوز دويامين را كانون توجه خود قرار دادهاند. كورتكس يريفرانتال نيز به علت مصرف زياد دويامين و ارتباطات متقابل با ساير مناطق مغز كه در توجه، بازدارى، انعطاف

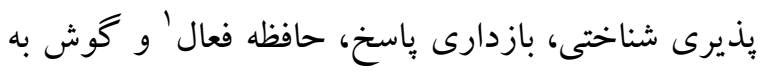

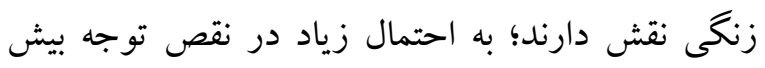
فعالى نقش دارند. نقص توجه بيش فعالى در ه تا 1 درصد كودكان مدرسهاى روى مىدهد و .9 تا هلى درصد آن ها در نوجوانى نيز هنوز مبتلا به نقص توجه بيش فعالى هستند. اختلال نقص توجه بيش فعالى به فراوانى با ساير اختلالات، همايند است از جمله اختلال

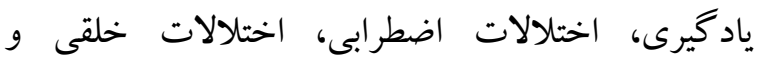

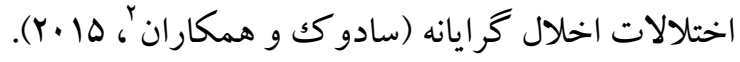
اختلال نقص توجه- بيش فعالى / تكانش گرى، سندرمى احسى عصبشناختى است كه معمولاً با ويز گیىهاى تكانش كرى، حواس برتى و بيش فعالى مشخص مى شود. از طرف ديخر اختلال كمبود توجه -بيش فعالى يك ونى اختلال عصب- روان شناختى است كه نظريه ها و ئزوهشهاى اخير بر نقش اصلى توجه به عنوان يكى از

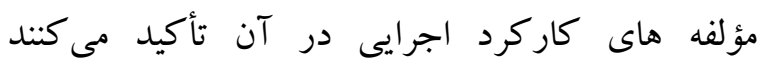

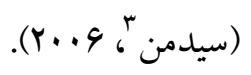

1- Active memory
2- Sadock
3- Seidman 
مبتنى بر آن تكاليفى را براى تقويت كار كردهاى شناختى مغز و بهبود علائم رفتارى طراحى مى نمايد. از اين رو هدف يزوهش حاضر مطالعه مقايسه تاثير خذارى دارودرمانى و توانبخشى شناختى بر روى حافظه فعال است. آقاجانى و همكاران (1 (I)، به بررسى اثربخشى آموزش نرم افزار ان بكك بر بهبود حافظهى فعال دانش آموزان

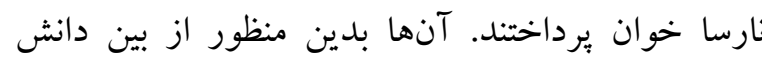
آموزان بسر دوم تا بنجم ابتدايى شهر رشت در سال

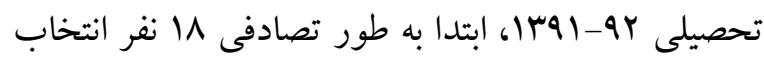
و سيس در دو كروه 9 نفره آزمايش و كنترل جاىدهى كردند. بـه منظور جمع آورى داده ها از آزمون خواندن و نارسا خوانى نما، نرم افزار سنجش حافظه كارى دانسيمن و كـارينتر و نرم افزار ان بكك استفاده كردند. طرح آزمايشى يزوهش آنها از نوع بيش بيش آزمون و و يس آزمون با گروه كنترل بود. نتـايج تحليل كوواريانس حاكى از تأثير مثبت آموزش نرم افزار ان بكك بر بهبود

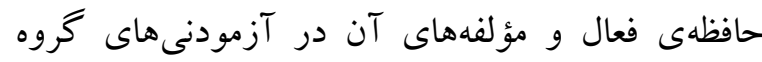
آزمايش در مقايسه با گروه كنترل بود. بر اين اساس آن ها نتيجه گرفتند كه نـرم افزار ان بكك اين مزيت را دارا است كه مى توان از آن در بهبود حافظه ف فعال كود كان نارساخوان و در نتيجه در حل مشكلات تحصيلى آنها

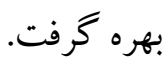
مساواتى و همكاران (هوسا)، به بثزوهشى در زمينه كاركردهاى اجرايى يرداختند. نتايج نشان داد از ميان كاركردهاى اجرايى حافظه فعال و متغير بازدارى سهم بيشترى در بيش بينى عملكرد رياضيات دارد.
مربوط به داروهاى محرك كاهش اشتها و اختلالهاى خواب است. كاهش اشتها با مرحله فعاليت بالينى دارو مطابقت دارد. ساير آثار جانبى نه جندان معمول شامل

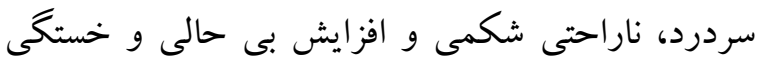
است. تجويز دراز مدت محر ككها ممكن است به رشد

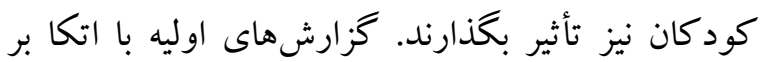
مواردى معدود حاكى از اين بوده كه محرككها از سرعت رشد كود كان مى كاهند. به طور كلى توافق عام بر اين است كه داروهاى محركك مىتواند تأثير منفى جزئى بر سرعت رشد بكذارند كه به آسانى با قطع موقت قابل جبران است؛ بنابراين اگر كاهشى در سرعت رشد مشاهده شود لازم است قطع موقت يا روشى جانشين در

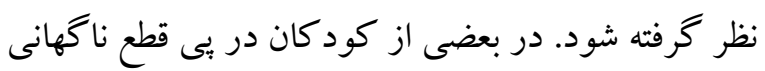
محر كها ممكن است بسرفت رفتارى كذراندهاى ظاهر شود. علائم معمولا كمتر از يكك روز طول مى كشد اما

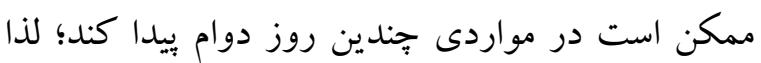
قطع تدريجى داروهاى محرك عاقلانه تر است (خرازى

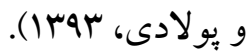
با وجود تعاريف و توضيحات بالا، ضرورت استفاده از برنامه هاى مداخله ای توانبخشى بر حافظه فعال كود كان داراى اختلال نقص توجه- بيش فعالى مشخص مى شود. لذا علاوه بر درمان دارويى با استفاده از برنامه توانبخشى شناختى كرتكس كه ساختارى Y ا جلسه اى داشته و مبتى بر حركت و فعاليت هاى بدنى شخص مراجع است؛ درمانكر با استفاده از تمرين هاى مختلف كامييوترى و عملى به همراه شكل هايى كه روى بنر حكك شده است اقدام به اجراى تمرين هاى مختلف كرده و به توانبخشى بـ شناختى مى بردازد. در طى اين جلسات درمانى، درمانگر اطلاعات حاصل از ارزشيابى جلسات رادر نظر گرفته و 
عملكرد بيشترى در يكك مقياس توجه بايدار آزمون عملكرد وييوسته و يكك مقياس زمان واكنش آزمون جفت كردن اشكال ناآشنا منجر شدند. آموزش توجه در مقايسه با درمان با داروى محرك، در زمينه توجه بايدار اثر بخشى كمترى نشان داد اما در مقياس زمان واكنش بر د مرمان دارويى برترى داشت.

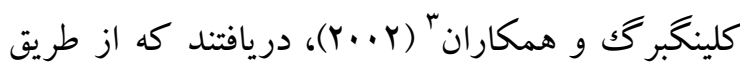
آموزش حافظه كارى مى توان عملكرد آزمودنى ها را در تكاليف حافظه كارى بهبود بخشيد و اينكه تأثير اين آموزش مى تواند به تكاليفى كه شخص مستقيماً در مورد آنها آموزش نديده ولى موفقيت در آنها مستلزم استفاده از حافظه كارى است تعميم يابد. آموزشها،

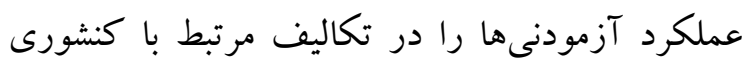
قشر ييش ويشانى (كنش هاى اجرايى) بهبود دادند و همجنين از ميزان فعاليت حركتى كودكان نارسا توجه افزون كنش كاستند. نتيجهى به دست آمده اين بود كه

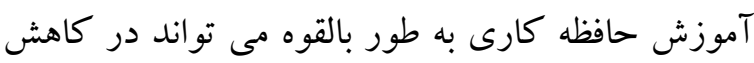
نشانه هاى اختلال نارسايى توجه /فزون كنشى فايده

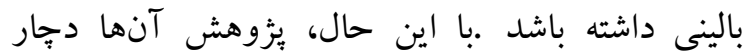
مسائل روششناختى عمدهاى بود. محدوديتهاى اين يزولهش موارد زير را شامل مى شد حجم نمونهى نسبتاً كو جكى، ناتوانى در جدا كردن اثر داروهاى محرك از از اثر آموزش حافظه كارى، عدم امكان قضاوت دربار 0ى اينكه آموزش حافظه كارى براى كدام يكك از خرد ريخت هاى اختلال نارسايى توجه/ فزون كنشى بيشتر مفيد است و عدم سنجش هاى بيخيرانه كه قضاوت دربارهى ماند گارى اثرهاى مشاهده شده را غيرممكن

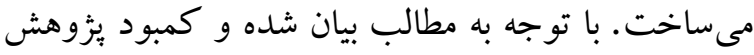

\footnotetext{
${ }^{3}$ - Klingberg et all
}

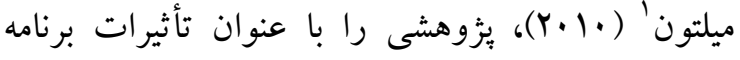
رايانهاى آموزش حافظه كارى بر روى توجه، حافظه كارى را در نوجوانانى مبتلا به نقص توجه /بيش فعالى و ناتوانىهاى يادگيرى بودند انجام داد. هدف اوليهى ثروهش اين بود كه آموزش رايانهاى حافظه كارى

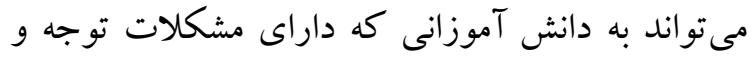
ياد گيرى هستند، كمك كند و هدف ديخر اين بود كه اين برنامهى رايانهاى مىتواند تمركز را افزايش دهد. نمونهى اين يُوهش شامل ها كودكك مبتلا به نقص رقد توجه/ بيش فعالى و ها نفر مبتلا به ناتوانى هاى ياديرى بود. روش بثزوهش بدين صورت بود كه دو

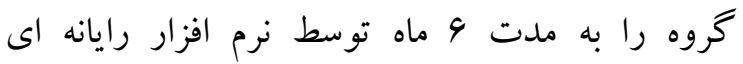

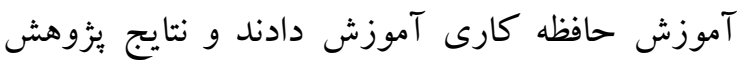
نشان داد كه اين نرم افزار آموزشى بر روى انعطاف يذيرى شناختى و حافظه كارى تأثير قابل توجهى دارد.

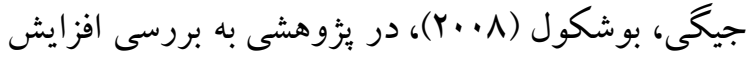
هوش سيال از طريق آموزش حافظهى فعال از نرم افزار ان بكك استفاده نمودند و نشان دادند كه ميزان افزايش در هوش سيال به شدت به مقدار آموزش بستخى دارد.

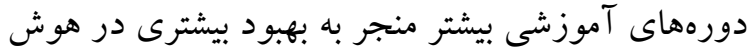
سيال مى شود و اثر آموزش وابسته به دور است.

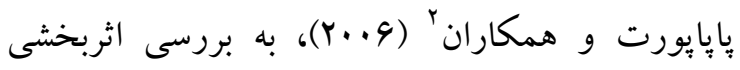
داروى متيل فنيديت و آموزش توجه در درمان اختلال نارسايى توجه / فزون كنشى از يك طرح تكك آزمودنى باز گشتى استفاده شد كه در آن دو شركت كننده مورد آنداد بررسى قرار كرفتند و كنترل طرح از طريق ارائه دارونما به يكى از اين دو آزمودنى تحقق يافت. هم متيل فنيديت و هم آموزش توجه در مقايسه با دارونما به بهبود إند

\footnotetext{
1- Milton

2- Pappaport et all
} 
كود كان بعد از تشخيص مشاور و ارجاع به روان بزشك تحت درمان دارويى قرار كرفتند، ها كود كك ديخر تحت برنامه توانبخشى شناختى قرار گرفتند و ها نفر ديخر نيز

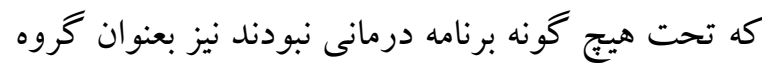
كنترل در نظر گرفته شدند. همجينين معيار ورود به اين

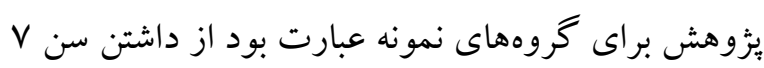
سال، عدم ابتلا به اختلالات يادگيرى و عقب ماندگى برى ذهنى و عدم مصرف دارو براى گرووه توانبخشى شناختى و مصرف مستمر دارو براى گروه دارو درمانى، همجينين معيار هاى خروج نيز عبارت بود از اين كه در صورتى كه كروه توانبخشى شناختى در حين اجراى بثروهش مصرف

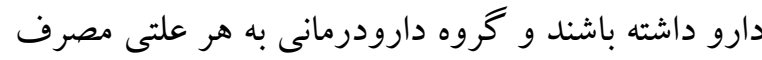

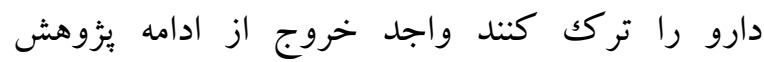
مى شدند. يس از مراجعه به اداره آموزش و يُوورش و كسب مجوزهاى لازمه دانش آموزان مورد بئوهش انتخاب شده و آن ها در گروه كنترل و آزمايش جاىدهى شهد شدند. در مرحله بعدى از كروههاى بثزوهش بيش آزمون به عمل

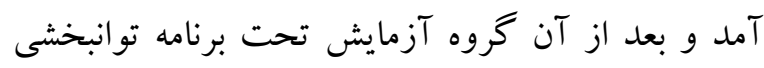
شناختى (دوازده جلسه) قرار گرفت و بـ بس از آخرين

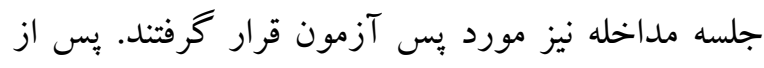

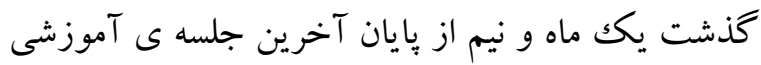

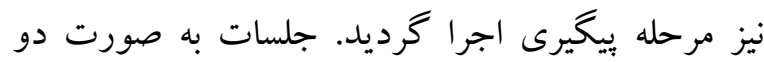

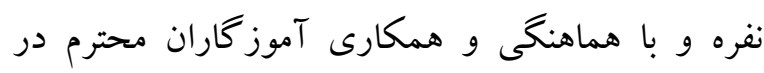
مدارس و در مركز مشاوره آموزش و برورش انجام شد. آموزش و تمرينات بدين صورت بود كه در هر جلسه با مرور بر مطالب و تكاليف جلسه قبل آغاز مى شد؛ سِّ يثزوهشكر، جلسه توانبخشى شناختى را شروع كرده و در پايان هر جلسه به دانش آموزان، تمريناتى در رابطه با آن
در اين زمينه در سطح كشور و با آكاهى از تفاوت آشكار ميان اثربخشى دارودرمانى، توانبخشى شناختى بر حافظه فعال كود كان مبتلا به اختلال نقص توجه- بيش فعالى، ضرورت انجام بزوهش توسط يثزوهشخر احساس شد كه اين يزوهش رادر شهر اهواز و بر روى كود كان مبتلا به اختلال نقص توجه- بيش فعالى اجرا شود تا نتايج حاصل از آن در آينده بتواند برنامه ريزان آموزش و برورش و كلينيك هاى روان شناسى را در برنامه ريزى هاى خود در راستاى تدوين برنامه هاى مدون به منظور ارائه آموزش هاى لازم به كود كان مبتلا به اختلال بيش فعالى، خانو ادههاى آنان، مربيان و معلمان آنان يارى نمايد.

روش براى آزمون فرضيه هاى يثوهش از تحليل كواريانس و آزمون تعقيبى بنفرونى استفاده شد. از لحاظ هدف نوع تحقيق از نوع كاربردى و از لحاظ روش، يِيش آزمونپِ آزمون با كروه كنترل و از نظر نوع كردآورى اطلاعات، روش برسشنامه است. جامعهى آمارى اين يُزوهش شامل كليهى دانش آموزان داراى اختلال نقص توجه- بيش فعالى شهر اهواز است. گروههاى نمونه

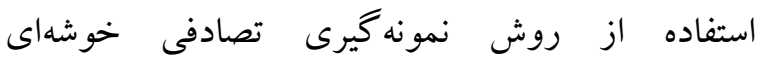
جندمرحلهاى، انتخاب شدند. بدين صورت كه ابتدا از جهار ناحيه آموزش و برورش شهر اهواز، به صورت قرعه كشى، ناحيه انتخاب شد و از بين كليه كود كانى كه با تشخيص بيش فعالى/ كمبود توجه در فاصله زمانى سه ماهه اول نيمسال اول تحصيلى 9V-99 به مركز مشاوره و خدمات روان شناختى ناحيه ب اهواز (هسته مشاوره) مراجعه نمودند؛ يرسشنامه كانرز اجرا شد و از بين تمامى اين افراد با تشخيص نقص توجه بيش فعالى، تعداد هانفر انتخاب شدند. از اين تعداد به شكل تصادفى ها نفر از 
آزمون بازآزمون فراخوانى ارقام ای/· است اين آزمون

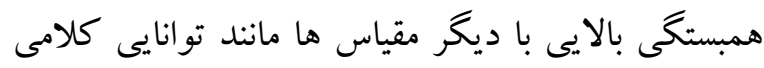
حافظه كوتاه مدت بينايى و يادگيرى كلامى و معنايى دارد و اعتبار آزمون-باز آزمون آن ل1/ • است (نجاتى، 1M روش باز آزمايى |N/ • به دست آمد. ساختار جلسه هاى برنامه توانبخشى شناختى كرتكس: اين بسته توانبخشى شناختى مبتنى بر حركت ساختار جلسهاى دارد و توسط نجاتى به عنوان ابزارى بومى جهت درمان و توانبخشى اختلالات مختلف از جمله اختلال نقص توجه- بيش فعالى تهيه و ساخته شده است و شامل تمرين هاى حركتى نيازمند شناخت جهت تقويت توجه، حافظه كارى، كنترل مهارى و انعطاف يذيرى شناختى است. در هر جلسه تمامى تمرينات حركتى با اهداف كسب مهارت هاى توجه انتخابى، توجه يايدار، انتقال توجه، حافظه كارى، كنترل مهارى و انعطاف يذيرى شناختى ارائه مى شوند و در صورت كسب مهارت توسط كودكك در زمينه هر كدام از تمرينات، نوع و شكل تمرين مورد نظر با حفظ هدف تغيير مى يابد و به تدريج متنوع تر و مشكل تر خو اهد شد.
جلسه داده مى شد كه در بيرون از مدرسه آن تكاليف را انجام دهند. سبس در جلسه بعدى آن ها مورد ارزيابى و بررسى قرار مى كرفتند. در بايان از حسن همكارى والدين تشكر به عمل آمد و به به پاس تشكر تاز همكارى والدين گروه كنترل به آن ها اعلام گرديد كه فرزندان آن ها مى توانند به طور رايگان از خدمات دوازده جلسهاى توانبخشى شناختى پِ از يايان بثزوهش بهره مند كردند.

ابزار آزمون فراخناى ارقام مستقيم (سنجش حافظه فعال): اين آزمون توسط كاتركول و بيكرينگك طراحى و در كود كان 9 و Vاله با موفقيت اجرا شده است. آزمايشخر رديفى از اعداد تكك رقمى تصادفى را مى خواند و آزمودنى بايد اعداد را به همان ترتيب كفته شده تكرار كند. رديف اعداد ابتدا س رقم دارند و به مرور به 9 رقم مى رسند. آزمون زمانى قطع مى شود كه كودكى دو بار متوالى يكك زنجيره نادرست را تكرار كند. هيج بازخوردى در طول آزمون به كودكى داده نمى شود.

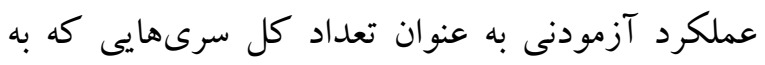
درستى يادآور شده اند نمره گذارى مى شود. اعتبار

\section{جدول ا شرح جلسات}

\begin{tabular}{|c|c|}
\hline محتواى جلسات & جلسه \\
\hline 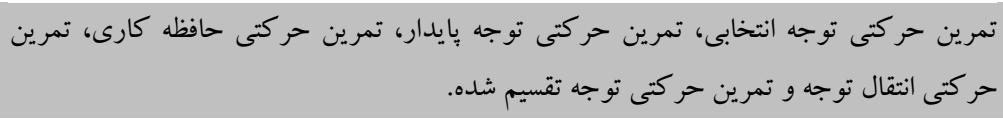 & جلسه هاى اول تا جهارم \\
\hline 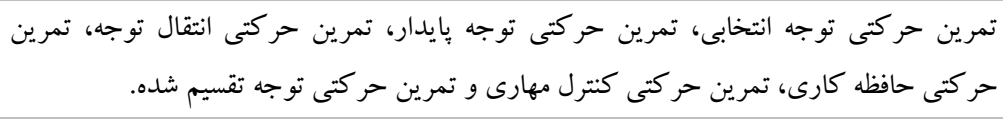 & جلسه هاى ينجم تا هشتم \\
\hline تمرين حر كتى توجه بايدار، تمرين حركتى كنترل مهارى و تمرين حركتى توجه تقسيم شده. & جلسه هاى نهم تا دوازدهم \\
\hline
\end{tabular}




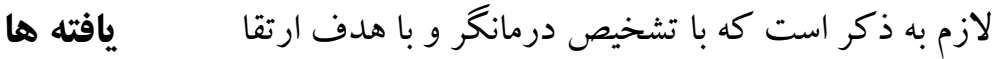
جدول ا ميانگين و انحراف معيار كاركردهاى اجرايى هائ تو انمندىهاى آزمودنى و با توجه به ضعف كودكى در بهر

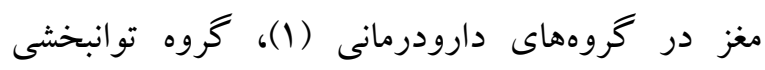
تمرينات مختلف انجام شده در جلسه هاى قبلى، در جهار شناختى (Y) و گروه گواه (r) در مراحل بيش آزمون، جلسه نهايى تمرينات نقاط ضعف آزمودنى بررسى و يس آزمون و يِيخيرى را نشان مى دهد. تمرينات تكرارى و تكميلى به تمرينات اين جلسات افزوده شد.

جدول 1 ميانكين و انحراف معيار كار كردهاى اجرايى مغز در كروههاى دارودرمانى (1)، كروه توانبخشى شناختى (r) و

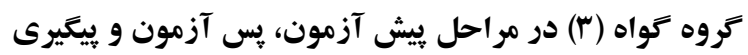

\begin{tabular}{|c|c|c|c|c|c|c|c|}
\hline \multicolumn{2}{|c|}{ بيغيرى } & \multicolumn{2}{|c|}{ يس آزمون } & \multicolumn{2}{|c|}{ بيش آزمون } & \multirow[b]{2}{*}{ كروه ها } & \multirow[b]{2}{*}{ متغير } \\
\hline معيار & ميانگين & معيار & ميانكين & معيار & ميانگين & & \\
\hline$\cdot / 09$ & $r / N \mu$ &.$/ 91$ & $\varphi / 4$ & $1 / .1$ & $r / r$ & كروه (1) & \\
\hline .194 & $9 / \Delta r$ & •/Ar & $\Delta / \Delta r$ & $1 / 11$ & $r / \pi r$ & كروه (Y) & حافظه فعال \\
\hline$\cdot|A|$ & $r / \pi r$ & $\cdot / V Y$ & $r / \pi r$ & $\cdot / 9$. & $r / \pi r$ & كروه (r) & \\
\hline
\end{tabular}

آزمون برابر سش/ و /1/11، در مرحلهى بِ آزمون برابر

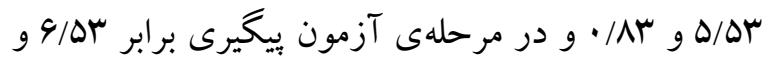

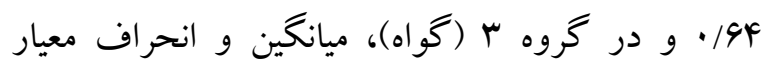
حافظه فعال در مرحلهى ييش آزمون برابر سش/ب و •9/9 •،

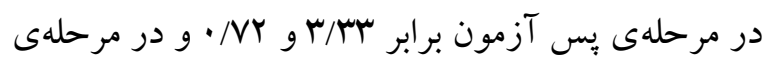

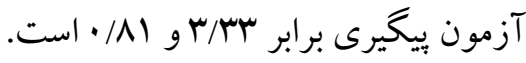

همان طور كه در جدول ا مشاهده مىشود، در گرووه 1 (دارودرمانى)، ميانگين و انحراف معيار حافظه فعال در هرد

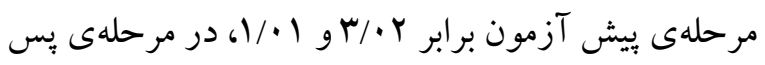

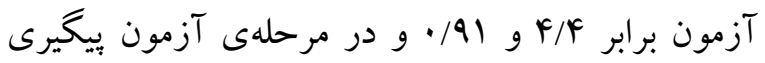

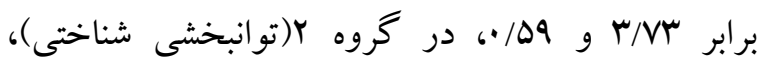
ميانگين و انحراف معيار حافظه فعال در مرحلهى بيش

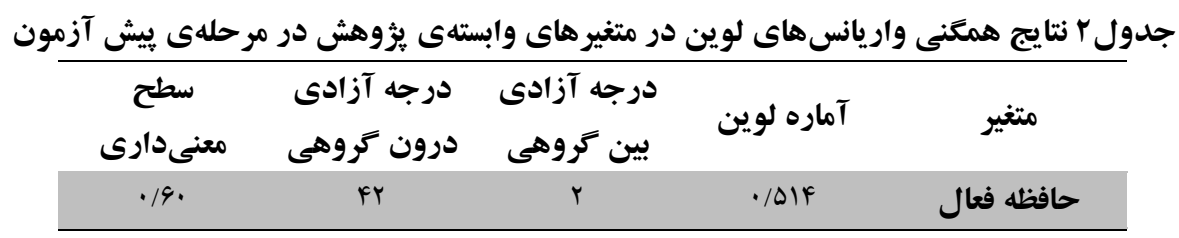

آزمايشى و گواه قبل از اعمال مداخله آزمايشى (در مرحله ييش آزمون) از نظر واريانس ها همخن بودند.
نتايج يافته هاى جدول r نشان دهنده همخنى واريانسها است كه با توجه به نتايج جدول فوق (ه •/ p> و و عدم معنادارى آزمون لوين، اجازه استفاده از آزمون تحليل

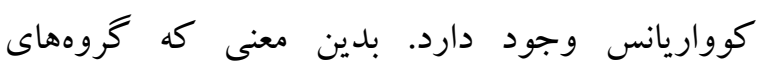




\begin{tabular}{|c|c|c|c|c|c|c|c|}
\hline \multirow{2}{*}{\multicolumn{8}{|c|}{ 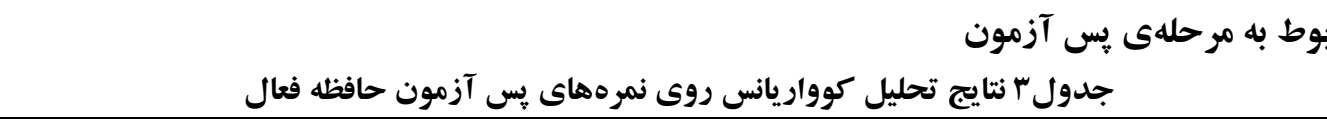 }} \\
\hline & & & & & & & \\
\hline اندازه & معنى سطحى & 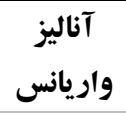 & 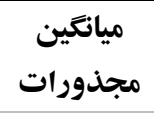 & 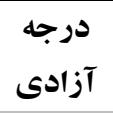 & 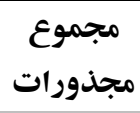 & متغير & منبع \\
\hline$\cdot / N^{F}$ &.$/ \cdot 1$ & $\Delta r / \Delta V$ & $10 / 09$ & r & $r M / / r$ & حافظه فعال & كروه \\
\hline
\end{tabular}

نشان مى دهند كه در متغيرهاى حافظه فعال بين كروههاى همان طور كه در جدول r ملاحظه مىشود آناليز دارودرمانى و توانبخشى شناختى و گواه تفاوت معنىدار واريانس تحليل كواريانس تكك متغيرى براى مؤلفهى ديده مى شود؛ بنابر اين فرضيه هاى بثزوهش تائيد مى شود.

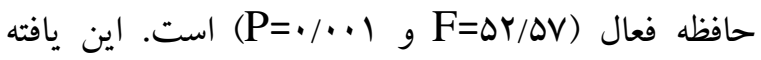

\begin{tabular}{|c|c|c|c|c|c|}
\hline \multicolumn{3}{|c|}{ شاخص هاى آمارى } & \multirow{2}{*}{\multicolumn{2}{|c|}{ كروه }} & \multirow[t]{2}{*}{ متغير } \\
\hline حد بالا & حد بِيين & خطاى معيار & & & \\
\hline F/VD & $F / I V$ & $\cdot / f$ & F/49 & دارودرمانى & \multirow{3}{*}{ فعال } \\
\hline$\Delta / W$ & $8 / 19$ & $\cdot /$ If & $\Delta / F \wedge$ & توانبخشى شناختى & \\
\hline$r / 91$ & $r / \cdot 1$ &.$/ 10$ & $r / r 1$ & كنترل & \\
\hline
\end{tabular}

همان گونه كه در جدول f مشاهده مى شود، ميانگين تعديل يافته و خطاى معيار مؤلفه حافظه فعال مطلوب و قابل ملاحظه است.

جدول ه نتايج آزمون تعقيبى بنفرونى براى مقايسه ميانكين هاى تعديل يافته كاركردهاى اجر ايیى مغز

\begin{tabular}{|c|c|c|c|c|c|}
\hline \multicolumn{6}{|c|}{ كروههاى آزمايشى و كواه در مرحله يس آزمون } \\
\hline معنى سطحى & خطاى معيار & ميانكينها & تعديل يانكين هاى & كروههاى مورد مقايسه & 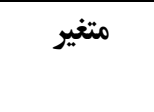 \\
\hline.$/ \cdot 1$ & $\cdot / r$ & $1 / 10$ & $r / \Gamma 1, F / F$ & كروه ا - گروه كو اه & \\
\hline$\cdot / . .1$ & $\cdot|r|$ & $r / I V$ & $r / \mu /, \Delta / F \wedge$ & كروه Y - گروه گواه & حافظه فعال \\
\hline.$/ .1$ & $\cdot / r$ & $-1 / \cdot r$ & $\Delta / F A, F / F q$ & r & \\
\hline
\end{tabular}

همان گونه كه در جدول هـ ملاحظه مىشود، تفاوت بين وجود دارد. تفاوت بين ميانگين گروه گواه و گروه

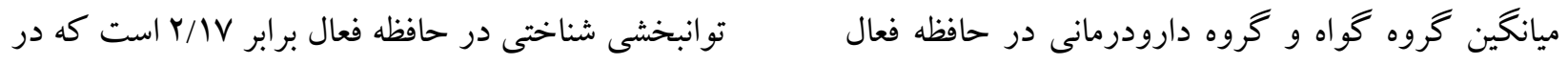

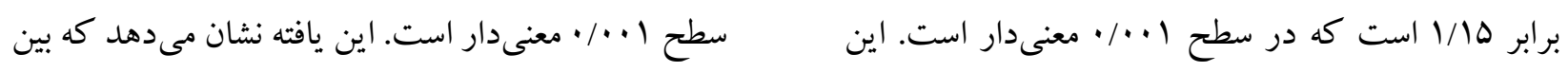

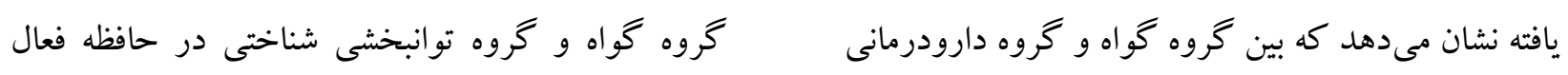

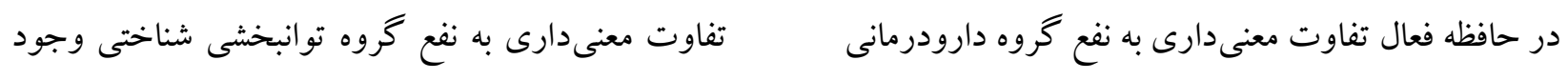


براى مقايسه گروههاى آزمايشى و گواه بر اساس نمره

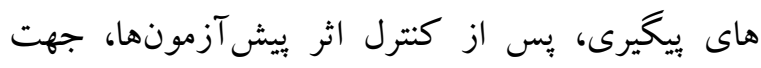
تعيين تأثير مداخله دارودرمانى و توانبخشى شناختى بر

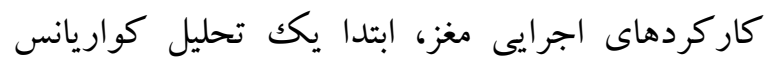

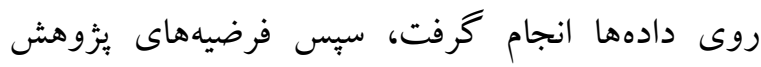

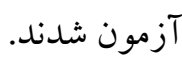

دارد و تفاوت بين ميانگين گروه دارودرمانى و گروه توانبخشى شناختى در حافظه فعال برابر r-1/- است كه در سطح | + • • معنىدار است. اين يافته نشان مىدهد كه بين گروه دارودرمانى و گرووه توانبخشى شناختى در حافظه فعال تفاوت معنىدارى به نفع گروه توانبخشى شناختى وجود دارد.

\section{يافته هاى مربوط به مرحلهى بييگيرى}

جدول 9 نتايج تحليل كوواريانس تك متغيرى در متن مانكووا روى نمرههاى پيگيرى كاركردهاى اجرايى مغز

\begin{tabular}{|c|c|c|c|c|c|c|c|}
\hline اندازه اثر & معنى سطارى & واريانس & مجذانكين & آزادى درجه & مجذوروات & متغير & منبع \\
\hline - /AF &.$/ . .1$ & $1 . \psi / Y \Lambda$ & 4.1 .9 & r & $1 \cdot / 19$ & حافظه فعال & كروه \\
\hline
\end{tabular}

در متغير وابسته(حافظه فعال)، بين گروههاى دارودرمانى و همان طور كه در جدول 9 ملاحظه مىشود متغير كنترل توانبخشى شناختى و گو اه تفاوت معنىدار ديده مىشود؛ تحليل كواريانس تكك متغيرى براى مؤلفهى حافظه فعال

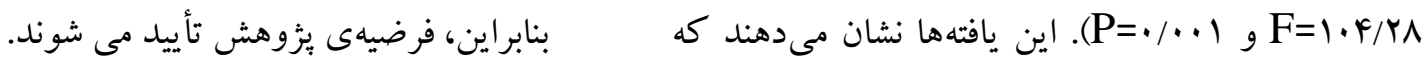

\begin{tabular}{|c|c|c|c|c|c|}
\hline معنى سطارى & خطاى معيار & تفاوتغينها & تعديل يانكين هافته & كروههاى مورد مقايسه & متغير \\
\hline$\cdot / \cdot 1$ & $\cdot / r$ & $1 / 10$ & $r / T /, F / F q$ & گروه ا - گروه گُواه & \\
\hline$\cdot / \cdot \cdot 1$ & $\cdot / r \mid$ & $r / / V$ & N/ & گروه r - گروه گواه & حافظه فعال \\
\hline.$/ . \cdot 1$ & $\cdot \pi$ & $-1 / \cdot r$ & $\Delta / F \wedge, F / F G$ & r & \\
\hline
\end{tabular}

سطح ا + · • معنىدار است. اين يافته نشان مىدهد كه بين كروه گواه و گروه توانبخشى شناختى در حافظه فعال تفاوت معنى دارى به نفع گروه توانبخشى شناختى وجود

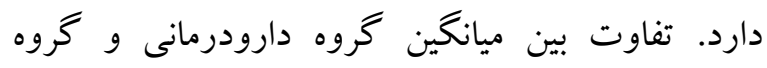
توانبخشى شناختى در حافظه فعال برابر r/I-1 است كه در سطح | +. • معنىدار است. اين يافته نشان مىدهد كه بين گروه دارودرمانى و گروه توانبخشى شناختى در
همان كونه كه در جدول V ملاحظه مىشود، تفاوت بين ميانگين گروه گُواه و گروه دارودرمانى در حافظه فعال

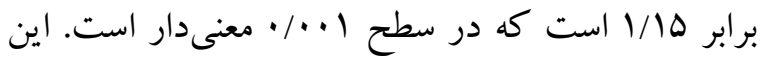
يافته نشان مى دهد كه بين گرووه گو اه و گروه دارودرمانى در حافظه فعال تفاوت معنى دارى به نفع گرووه دارودرمانى

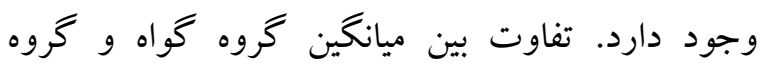
توانبخشى شناختى در حافظه فعال برابر Y/IV است كه در 
نتايج يزوهش نشان دادند توانبخشى شناختى بر حافظه فعال داراى تأثيرات بيشترى در مقايسه با درمان دارويى بروني است؛ به طورى كه كودكان مبتلا به اختلال فوق الذكر پِ از قرار گرفتن در جلسه هاى درمانى توانبخشى شناختى در مؤلفه حافظه فعال بهبود قابل تو جهى يافتند. بنا

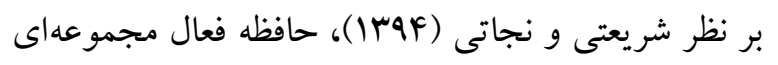
از فرآيندهاست كه به فرد اجازه مىدهد تا زمان به كار گيرى اطلاعات و يا رمز گردانى آن ها رادر ذهن نخه

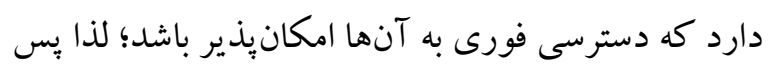
از بر گزارى جلسه هاى توانبخشى شناختى كر تكس ميز ان حافظه فعال كود كان افزايش ييدا كرد و اين يافته نشان بران داد كه هنگامى كه توانبخشى شناختى به عنوان تنها راه

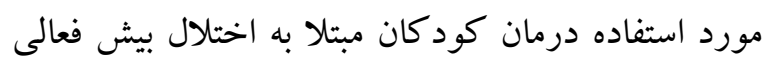
انتخاب شود داراى تأثيرات يايدارترى نسبت به انتخاب

$$
\text { درمان دارويى به تنهايى است. }
$$

لذا در روش توانبخشى شناختى كه در آن از انواع فنون توانبخشى و فرد روان شناس بهره مى برد داراى تأثير و يايدارى بيشترى است. لذا هدف از توانبخشى شناختى تقويت و يا تثبيت مجدد الكوهاى رفتارى ويشين و نيز تثبيت الكوهاى رفتارى جديد براى انجام فعاليت يا ارائه مكانيسم هاى شناختى جهت جبران عملكرد هاى آسيب ديده سيستم عصبى است. از محدوديت هاى اين بزوهش مى توان به كم بودن بيشينه هاى داخلى و خارجى كه در زمينه توانبخشى شناختى بر روى كود كان مبتلا به اختلال نقص توجه- بيش فعالى بثزوهش و تحقيق كرده باشند نام برد. همجنين با توجه به تأثيرات مثبت برنامه توانبخشى برونى شناختى كرتكس بر روى حافظه فعال دانش آموزان مبتلا به اختلال نقص توجه- بيش فعالى بيشنهاد مى گردد

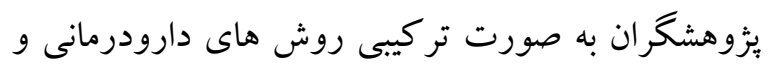

حافظه فعال تفاوت معنىدارى به نفع گروه توانبخشى شناختى وجود دارد.

هدف اين يثزوشش بررسى مقايسه اثربخشى دارودرمانى و تو انبخشى شناختى بر حافظه فعال كود كان مبتلا به اختلال نقص توجه- بيش فعالى شهر اهواز بود. روش هايى براى درمان كود كان مبتلا به اختلال نقص توجه- بيش فعالى به كار برده شد تا روند درمان سريع تر و با كيفيت بهترى صورت يذيرد. مداخله هاى صورت گر فته با استفاده از برنامه توانبخشى شناختى كورتكس باعث بهبود حافظه

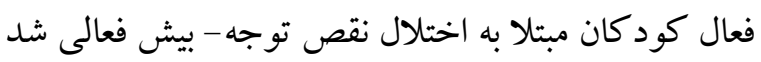
كه ميزان تأثير مداخله در روش توانبخشى شناخته به نسبت روش دارودرمانى بيشتر بود. لذا كودكانى كه تحت برنامه تو انبخشى شناختى قرار كرفتند به علت اينكه با روشى كاملاً طبيعى و با استفاده از تمرين هاى حر كتى و فكرى مورد درمان قرار كرفتند در مؤلفه حافظه فعال بهبود بيشترى را به نسبت گروهى كه فقط تحت درمان

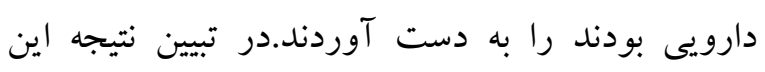
يثزوهش مى توان كفت كود كانى كه تحت برنامه تو انبخشى قرار گرفتند با استفاده از تمرينهاى فكرى و وان حركتى در مؤلفه حافظه فعال به بهبودى بيشترى دست يافته اند.لذا در روش توانبخشى شناختى كه در آن فرد از

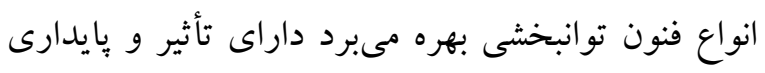
بيشترى است. بنابراين نتايج حاصل با يافتهاى برخى از

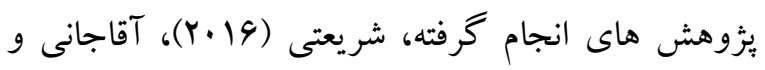

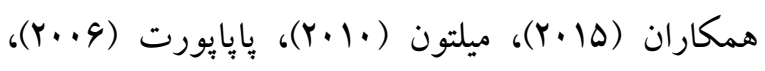
سيدمن (Y. (Y. ) هماهنگك و همسو است. 
Adolescents With Severe ADHD/LD, psychology joumal, 1(14), 120-122.

Pappaport N, Chubinsky P. (2006). The meaning of psychotropic medication for children, adolescents, and their families. J Am Acad Child Adolesc Psychiatry.2006; 39: 11981200.

Saduk B, Saduk V, \& Roe P. (2015). Summary Kaplan and Sadukh Psychiatry. Translation: Ganji, Mehdi. 2015. Ed. Eleven. Peacemaker Savalan.

Seidman LJ. (2006). Neuropsychological functioning Archive of SID in people with ADHD across the lifespan. Clinical Psychology Review, 26, 466-485.

Shariati Sh, Nejati Vahid. (2016). Effectiveness of rain rehabilitation program on executive functions of children with attention deficit hyperactivity disorder. Master's Thesis. Shahid Beheshti University of Tehran. (In Persian).

$$
\begin{aligned}
& \text { توانبخشى شناختى را نيز مورد بررسى قرار داده تا ميزان }
\end{aligned}
$$

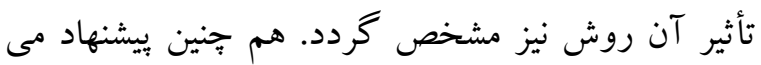

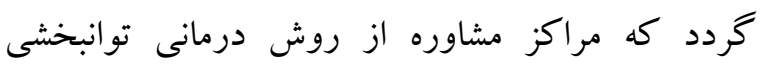

$$
\begin{aligned}
& \text { شناختى استفاده نمايند تا به مرور از ميزان مصرف داروى } \\
& \text { مبتلايان به اين اختلال كاسته شود. }
\end{aligned}
$$

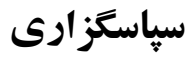

$$
\begin{aligned}
& \text { در بايان از تمامى دوستان و همكارانى كه در اجراى اين } \\
& \text { يثزوهش به ما يارى رساندند نهايت تشكر و قدردانى را }
\end{aligned}
$$

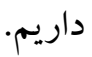

\section{References}

Aghajani N, Khanzadeh H, Kafi AA, Mossey S. ( 2015). The Effectiveness of Beck's Software Training on Improving Active Memory in Dyslexic Students. Joumal of Leaming Disabilities. Volume 4, Issue 3, Spring 2015. ( In Persian).

Conners C. (2002). Conners' rating scales: revised technical manual. North Tonawanda (NY); Multi-Health Systems, online]. Avalable from URL: http: www.mhs.com [Assessed 2008 Mar 3.

Conners CK, Sitarenios G, Parker JA, \& Epstain JN. ( 1978). Revision and restandardization of the Conners' Teacher Rating Scale :Factor structure, reliability, and criterion validity. Journal of Abnormal Child Psychology, 26 (4), 279-292.

Kaplan H, \& Saduk B. (2001). Summary psychiatry. Volume III. Translator. Nusratullah Pvrafkary.2006. Tehran: Water city.

Klingberg T, Forssberg H, \& Westerberg H. (2002). Training of working memory in children with ADHD. Joumal of Clinical and Experimental Neuropsychology, 24, 781-91.

Milton H. (2010). Effects Of A Computerized Working Memory Training Program On Attention, Working Memory, And Academics, In 